September 2006

\title{
The Destruction of the Armenian Church during the Genocide
}

Simon Payaslian

Follow this and additional works at: https://digitalcommons.usf.edu/gsp

\section{Recommended Citation}

Payaslian, Simon (2006) "The Destruction of the Armenian Church during the Genocide," Genocide Studies and Prevention: An International Journal: Vol. 1: Iss. 2: Article 6.

Available at: https://digitalcommons.usf.edu/gsp/vol1/iss2/6

This Articles is brought to you for free and open access by the Open Access Journals at Digital Commons @ University of South Florida. It has been accepted for inclusion in Genocide Studies and Prevention: An International Journal by an authorized editor of Digital Commons @ University of South Florida. For more information, please contact digitalcommons@usf.edu. 


\title{
The Destruction of the Armenian Church during the Genocide
}

\author{
Simon Payaslian \\ Center for Holocaust and Genocide Studies, Clark University
}

The scholarship on the Armenian Genocide has expanded enormously during the past three decades. Most of these works have focused on the causes and consequences of the genocide, Western responses to and Turkish denial of the genocide, and, more recently, Armenian-Turkish reconciliation. The role of the Armenian Apostolic Church, however, has received little attention in the literature. In addition to its ecclesiastical duties, the Armenian Church has over the centuries performed various secular functions, including, in the Ottoman Empire, acting as the principal representative agency for the Armenian millet. This article briefly examines the responses of the Armenian Patriarchate in Constantinople to the internationalization of the Armenian Question and then focuses on the three ecclesiastical leaders who played a central role in attempts to address the crises enveloping the Armenian people during World War I: Patriarch Zaven Der Yeghiayan of the Armenian Patriarchate in Constantinople, Catholicos Sahag II Khabayan of the Great House of Cilicia at Sis, and Catholicos Kevork V Surenyants of the Mother See at Echmiadzin. All three witnessed the destruction of their people and had the unenviable task of searching for the means to end the human catastrophe. Indeed, the Armenian Church itself, a most conservative institution harboring the utmost loyalty to the Ottoman Empire, in the end became a victim of the genocidal scheme of the Young Turk regime.

\section{Introduction}

G. Marcar Gregory prefaces his English translation of The Church of Armenia by Archbishop Maghakia Ormanian, who served as the Armenian patriarch at Constantinople from 1896 to 1908, with the following observation: "The Church of Armenia has been crushed for centuries between the upper and the nether millstones of political rivalry and conquest, and during these long ages of 'religious liberty' has had to be secured by sheer independence of character and the shedding of much blood." Indeed, since its emergence in the fourth century, the Armenian Church has played a central role in Armenian community life, and Christianity has remained deeply intertwined with national institutions and identity. The Church, in addition to representing spiritual leadership, has also performed various ecclesiastical and secular functions, including diplomacy between Armenians and other nations and religious communities.

The Armenian Church was first established at the Holy See of the Mother Church at Echmiadzin, now in the Republic of Armenia. The vagaries of regional geopolitics and cycles of Armenian political and cultural awakening and decline led to the emergence of other ecclesiastical centers, most prominent among them the Catholicosate of Aghtamar, the Catholicosate of the Great House of Cilicia at Sis, ${ }^{2}$ the Patriarchate in Constantinople, and the Patriarchate in Jerusalem. By the late nineteenth century, when historic Armenian lands had been divided between the Russian and Ottoman empires, the Holy See of Echmiadzin represented Armenians in 
the former, while the Patriarchate in Constantinople, established in 1461 as the millet başi (head of the nation) under Sultan Mehmed II, represented Armenians in the Ottoman Empire. The Catholicosate of Cilicia had emerged as an autonomous entity in 1441 at Sis, once the capital of the Armenian kingdom in Cilicia, but the prominent role assigned to the patriarchate in the imperial capital reduced its status and limited its jurisdiction to a handful of dioceses. The Patriarchate in Jerusalem, whose roots are said to date back to the fourth century, had been closely associated with the authority of its counterpart in the Ottoman capital but served in a subordinate position until after World War I. The Catholicosate of Aghtamar, located in the Armenian vilayet (province) of Van, was founded in the twelfth century by the opponents of the Mother See. When the last catholicos at Aghtamar, Khachadur Rshduntsi, died in 1895, the Ottoman authorities left it dormant; by the time war broke out in 1914, vacancy had bred atrophy. ${ }^{3}$

After the outbreak of World War I, as the genocidal crises began to envelope the Ottoman Armenians, Patriarch Zaven Der Yeghiayan of the Armenian Patriarchate in Constantinople (1913-1922), Catholicos Sahag II Khabayan of the Great House of Cilicia at Sis (1903-1939), and Catholicos Kevork V Surenyants at the Mother See of Echmiadzin (1911-1930) witnessed the destruction of their people and had the unenviable task of searching for the means to end the human catastrophe. Indeed, the Armenian Church itself, a conservative institution with a long tradition of loyalty to the Ottoman Empire, in the end became a victim of the genocidal scheme of the Young Turk regime.

\section{The Patriarchate of Constantinople and the Armenian Question}

The Ottoman state was in essence a theocratic political system, whereby the sultan, as the Caliph (successor to the Prophet Mohammed), represented the supreme political and religious authority. The political system was based on the millets (religious communities) that provided for representation and supervision of the ethnoreligious communities in the empire, and within that system the Armenian Apostolic community constituted a separate millet, headed by the Patriarchate in Constantinople, where the patriarch served not only as the spiritual leader of the Armenian Apostolic community in the empire but also as the administrative agency responsible for Armenian educational and judicial affairs. Following Islamic tenets, Ottoman society was divided between believers (Muslims) and "tolerated infidels" (non-Muslims), a system that rested on the principle of inequality: Ottoman law relegated non-Muslim communities to a subordinate status, subject to various officially sanctioned discriminatory policies. Conditions across the empire deteriorated rapidly as a result of the economic and military decline experienced by the late eighteenth and early nineteenth centuries. By the late nineteenth century, the ethno-religious boundaries had not only hardened but also become an integral part of the escalating conflict between Turks and Armenians, although the Armenian community had for centuries represented the exemplary loyal millet (Millet-i Sadıka). ${ }^{4}$ The role of the patriarch grew immeasurably more complicated as Ottoman officials and bands of marauding Kurds and Circassians routinely subjected Armenians to various forms of officially sanctioned and unofficial brutalities. While the Ottoman government resorted more frequently to repressive measures toward the Armenian millet, especially in matters of taxation, the Armenian ecclesiastical leadership nevertheless continued to advocate cooperation with officials at all levels of government. ${ }^{5}$ 
In the meantime, international and domestic pressures from both Muslims and non-Muslim communities demanding administrative reforms, liberalization, and democratization had led to the promulgation of the Tanzimat (reorganization) reforms. Sultan Abdul Mecid (1839-1861) had introduced the Hatt-ı Şerif of Gülhane (the Noble Rescript) in 1839 and in 1856 the HattHumayun (the Imperial Rescript), promising civil and political rights, physical security, and equality. ${ }^{6}$ In 1847, the Sublime Porte had approved the creation of the Armenian Spiritual Council (religious) and the Supreme Council (lay), both under the directorship of the Patriarchate in Constantinople; in 1863, the government had issued an imperial iradé (decree) also ratifying the Armenian National Constitution. ${ }^{7}$

Promises of structural reform and just governance, however, remained confined to the halls of pomp and ceremony. Armenian calls for security of life and property and for an end to arbitrary rule, corruption, and heavy taxation went unheeded. The Ottoman government, increasingly mired in economic and military difficulties, especially in the aftermath of the Crimean War (1853-1856), was determined to reverse the course of imperial decline. In fact, rather than implement the promised reforms, it resorted to repressing and persecuting opposition movements, which, in turn, instigated further agitation for anti-government action among various groups, particularly young intellectuals, including Armenians, trained in European universities. Some Armenians also organized self-defense societies for protection against atrocities. $^{8}$

Meanwhile, eastern Armenia, which was drawn into the Russian orbit during the reigns of Peter the Great (1689-1725) and Catherine the Great (1762-1796), was similarly subjected to repressive government measures in the first half of the nineteenth century, as the Russian Empire consolidated power in the Caucasus. While Yerevan and Nakhichevan were granted the status of Armianskaia Oblast-an "autonomous" Armenian province-Czar Nicholas I, in March 1836, instituted the Polozhenie restricting the activities of the Armenian Church in political matters and establishing czarist control over the church. ${ }^{9}$ The Polozhenie required that the Catholicosate at Echmiadzin conduct its relations with the outside world through the Russian Ministry of Foreign Affairs. The Mother See at Echmiadzin nearly lost its autonomy under czarist pressure. ${ }^{10}$

In both Russian and Ottoman Armenias, matters had improved little when the Russo-Turkish war broke out in 1877. In the Ottoman Empire, the outbreak of the war resulted in the suspension of the constitution of 1876 and the termination of the Tanzimat in 1878, as the new sultan, Abdul Hamid II (1876-1908/9), deeply distrustful of people beyond his immediate control, could not countenance even the facade of reforms. The sultan's resistance notwithstanding, the San Stefano and Berlin treaties signed after the Russo-Turkish war led to the internationalization of the Armenian Question. ${ }^{11}$ Neither the Mother See at Echmiadzin nor the Catholicosate of Cilicia was in a position to assume an active role in the process, since they lacked formal jurisdiction in matters of Ottoman diplomacy. Instead, as had been the case during most of the nineteenth century, the strenuous responsibility of pursuing the Armenian Question fell most heavily upon the shoulders of the Patriarchate in Constantinople. The patriarchate was the only official representative institution for Ottoman Armenians, but the involvement of the higher clergy in European diplomacy ineluctably antagonized the Sublime Porte and raised suspicions about the role of the church in its professions of loyalty. 
In fact, two contradictory patterns were set in motion in the orientation of the Armenian Patriarchate with the internationalization of the Armenian Question in the late nineteenth century. On the one hand, despite the deepening crisis, the church in general remained a conservative institution and rejected association with the opposition. Only a small minority among the clergy participated in political activities. On the other hand, the Patriarchate in Constantinople was also compelled to serve as a conduit for the expression of Armenian grievances before the Sublime Porte, as well as in international diplomatic relations. Patriarch Nerses Varzhabedian (1874-1884) and the higher clergy generally encouraged loyalty to the sultan, and during the RussoTurkish war the patriarch issued an encyclical urging Armenians to support the Ottoman army. However, chronic maladministration on the part of Ottoman officials at all levels of government and the geopolitical situation created by the Russo-Turkish war denied the Armenian patriarchate the luxury of facile solutions through declarations. Growing protests by Armenians in the eastern provinces demanding protection from their Turkish, Kurdish, and Circassian attackers, coupled with the Russian military victories during the war, emboldened Patriarch Nerses to travel to San Stefano to petition the czarist government to include in the post-war peace treaty a provision granting administrative autonomy and protection for the physical security of his flock in the Armenian provinces. Russia, after all, Armenians believed, had repeatedly presented itself as the "liberator" of Christians from the Turkish yoke, and the convergence of interests might finally lead to the desired outcome. ${ }^{12}$

Under the Treaty of San Stefano (3 March 1878), Russia gained vast territories in historic Armenian lands. This treaty also stipulated that the Sublime Porte would ameliorate conditions in the Armenian provinces "without further delay" and protect Armenians against Kurdish and Circassian attacks. The Russian military would withdraw from the conquered territories only after conditions for the Armenians had improved. European powers, most prominently Britain, viewed the treaty as a Russian pan-Slavic attempt to dismember the Ottoman Empire and, accordingly, insisted that it be renegotiated. The Russian government agreed and sent its representatives to Berlin to meet with the European powers. ${ }^{13}$

With the blessing of the Patriarchate in Constantinople, an Armenian delegation of two archbishops and two laymen, led by Archbishop Mgrdich Khrimian, who had served as patriarch at Constantinople from 1869 to 1873 (later Catholicos at Echmiadzin, 1892-1907), traveled to Western capitals hoping to garner diplomatic support for the Armenian cause at the Berlin conference. While representatives of the major powers met, however, the Armenian delegation was simply ignored and left to wait outside. Armenian disillusionment at Berlin turned into utter frustration upon learning the results of the conference. The Russian government had succumbed to British pressure and signed a new treaty (the Treaty of Berlin, 13 July 1878), thereby agreeing to withdraw its army from the conquered territories. To save face on the home front, the European powers included a provision requiring that the Sublime Porte implement, under European collective supervision, the necessary reforms for the safety of its Armenian subjects. The Armenian patriarchate and, most notably, Archbishop Khrimian protested the bankruptcy of Western arbitration regarding Armenian concerns. ${ }^{14}$

Growing disillusionment with the European powers and the inability of the Armenian Church to effect changes led to the radicalization of Armenian nationalist movements and the emergence of loosely structured groups such as the Union of Salvation (founded in Van in 1872), the Black Cross Society (Van, 1878), and the 
Protectors of the Fatherland (Erzurum, 1881). This was followed during the same decade by the founding of the three major political parties: the Armenagan Party (Van, 1885), the Hnchagian Party (Geneva, 1887), and the Armenian Revolutionary Federation, or Tashnagtsutiun (Tiflis, 1890). ${ }^{15}$ While Armenians in general, albeit with great trepidation, welcomed the party activists to their communities for the physical security they promised, the socialist and revolutionary ideologies these parties espoused nevertheless alarmed the more conservative institutions and classes.

The Armenian Church and members of the wealthier classes, who worked as bankers, merchants, and civil servants in the capital and other major urban centers, viewed the emerging nationalist movement among their compatriots as a nuisance and radical revolutionary activities as a direct threat to their status in official circles and society at large. ${ }^{16}$ Alarmed by the growing Armenian militancy and determined to maintain the status quo, Patriarch Nerses Varzhabedian, in a message to the Armenian National Assembly, pledged loyalty to the sultan, with the expectation that the Sublime Porte would implement the promised reforms. The patriarchate, for its part, would continue to direct all efforts to ameliorate the Armenian situation with allegiance to the Ottoman government in mind. ${ }^{17}$

No expressions of fidelity, however, could assuage the fears of Sultan Abdul Hamid II, who viewed all Armenian political activity as subversive. Armenian demands for administrative reforms and political liberalization and, more to the point, the involvement of the Armenian Patriarchate in the internationalization of the Armenian Question further antagonized the sultan, who, growing ever more suspicious of Armenian intentions, reacted by mobilizing his Muslim subjects against the Armenian community. When Armenians resorted to armed self-defense, particularly in Sasun, in the summer of 1894 to repel attacks on their villages and families by the Hamidiye regiments and Circassians, the government organized wholesale massacres that, by 1896, resulted in the deaths of more than 100,000 Armenians, with estimates as high as $300,000 .^{18}$ Johannes Lepsius, a German Protestant missionary, detailed the atrocities committed against the Armenians. He reported that a clear pattern emerged in the strategy and method of the massacres, beginning in early October in the province of Trebizond (Trabzon) and rapidly spreading across the six Armenian vilayets of Erzurum, Bitlis, Kharpert (Mamuret ul-Aziz), Sivas, Van, and Diyarbekir, reaching Aleppo, Adana, and Ankara by late November. Lepsius estimated that 646 villages were forcibly converted to Islam, 645 churches and monasteries were desecrated and destroyed, and 328 churches were turned into mosques. ${ }^{19}$ The Patriarchate in Constantinople could not have anticipated massacres of such magnitude, despite the patently hostile attitude of the Sublime Porte toward the Armenians.

By 1894, Varzhabedian had been succeeded by the lackluster Patriarch Harutiun Vehabedian (1885-1888), followed by Khoren Ashegian (1888-1894). Neither Vehabedian nor Ashegian was prepared for the task at this juncture, and the patriarchate failed to pursue the Armenian Question. Patriarch Mateos Izmirlian (1894-1896) sought to reinvigorate the patriarchate after a decade of decline, but his open support for the Armenian nationalist movement undermined his own authority in relations with the Sublime Porte. ${ }^{20}$ The fact that Patriarch Izmirlian had, in the eyes of the government, maintained close ties with nationalists only exacerbated the situation and marginalized him. Further, easily swayed by European promises of support, Izmirlian expected European humanitarian and military intervention to protect the Armenians. Convinced of that support, Izmirlian demanded that the sultan 
punish all officials and individual Turks and Kurds who had committed atrocities against Armenians during the massacres. As Maghakia Ormanian has noted, there was a wide chasm between Izmirlian's expectations and political realities. The government finally removed Patriarch Izmirlian from his post in 1896 and exiled him to Jerusalem. ${ }^{21}$ His successor, Archbishop Ormanian, who served until 1908, brought to the patriarchate enormous energy in matters of cultural and educational affairs, as attested by such publications as The Church of Armenia and, more significantly, by his Azkabadum ("History of the Nation"). He was ardently loyal to the sultanate, but his ultra-conservative stance on matters of reforms and socialist ideology rendered him unpopular among Armenian activists. ${ }^{22}$

The repressive regime, economic difficulties, and recurring bloodshed convinced not only Armenians but also the other nationalities in the empire, including Turks, of the urgent need for fundamental structural improvements and changes in political leadership. Beginning in the late nineteenth century, the Young Turks, composed of intellectual, political, and military leaders, along with the Armenian and other Muslim and non-Muslim nationalist movements, agitated for such changes. The Committee of Union and Progress (Ittihad ve Terakki Cemiyeti), or CUP, created by the Young Turks, sought to mobilize the revolutionary movement against Sultan Abdul Hamid. ${ }^{23}$ The Young Turk revolution in July 1908 was welcomed by both Christians and Muslims. As British ambassador Sir Gerard Lowther reported from Constantinople, "priests met with hodjas in the market place and publicly embraced, and liberty, equality, and fraternity became the order of the day." 24 Ormanian, too closely associated with the sultanate, resigned as patriarch under questionable circumstances immediately after the revolution, and the new regime, combining its political victory with the moral, returned Izmirlian from his exile in Jerusalem as patriarch. Within months, however, Izmirlian was elected as Catholicos of the Mother See at Echmiadzin. ${ }^{25}$

The Young Turk revolution and the reinstitution of the constitution of 1876 seemed, albeit briefly, to have inaugurated a period of revival in Armenian cultural and political life. The liberal faction of the Young Turk leadership advocated the implementation of civil and political rights within a parliamentary system, but neither domestic nor international conditions proved conducive to further liberalization. The nationalist factions emphasized the economic and military revival of the Ottoman Empire and mounted an insurmountable opposition, and the new government proved too fragile in its formative stages to counter such challenges, particularly against the reactionary forces of the sultan. During the ensuing struggle for power in April 1909, two rounds of massacres were launched against the Armenians, in the region of Adana, that by the end of the month left more than 20,000 Armenians dead. ${ }^{26}$ Patriarch Hovhannes Arsharuni and Catholicos Sahag pleaded for calm and an end to the bloodshed. After peace was restored, the patriarchate dispatched teams of priests, doctors, intellectuals, and other community leaders and public servants to help in the recovery process. ${ }^{27}$ Such experiences, however, could not prepare the Armenian leadership for the more sinister schemes yet to unfold.

The ultra-nationalists within the CUP, led by Mehmed Talât, Ismail Enver, and Ahmed Cemal, gained in power particularly during the Balkan wars as military defeats forced the Ottoman Empire to make further territorial concessions. In 1913, Enver and his supporters orchestrated a military coup and established the Ittihadist military dictatorship. The Ittihadists relied on the ideology of Pan-Turkism/Pan-Turanism to strengthen their power and political legitimacy, 
as they pressed forward to create an exclusively Turkish state at home and aspired to eastward expansionism toward Central Asia for the unification of all Turkic peoples. ${ }^{28}$ Christopher Walker has correctly noted that "The Armenians failed to grasp the nature of Turkism. They continued to see themselves as Christians .... Religion was an integral part of being an Ottoman Armenian, so a nonreligious ideology was hard to comprehend. They found it almost impossible to see what it meant to be up against a nonreligious, race-based ideology." 29 The Young Turk regime viewed the Armenian people as an impediment to the Turkification of the empire and to the regime's Pan-Turkic expansionist and unification schemes-policies that contributed to the Armenian Genocide.

\section{The Genocide}

Despite the signs of trouble, most Armenians continued to hope that conditions would improve. In 1910, Archbishop Ormanian concluded his famous treatise on the Armenian Church with the statement that the Armenian was "impressed with the conviction that the Church, which has protected him in the past, will continue to protect him in the future."30 In a letter dated 19 November 1913 (6 November according to the Ottoman calendar), the popular Armenian poet Vahan Tekeyan congratulated the newly elected Armenian Patriarch Zaven Der Yeghiayan at Constantinople and expressed his belief that the Armenian people had found in His Holiness a person capable of leading the nation toward a better future. ${ }^{31}$ Such expectations were reinforced by the Reform Act of 8 February 1914, initiated by petitions to the Russian government by Catholicos Kevork V Surenyants at Echmiadzin, in cooperation with the Armenian National Assembly, the National Executive, and the Patriarchate in Constantinople. Signed by Ottoman Grand Vizier Said Halim and the Russian chargé d'affaires Konstantin N. Gulkevich, the Reform Act promised administrative restructuring to facilitate better distribution of bureaucratic and political authority. ${ }^{32}$ The outbreak of World War I in July dashed all such hopes, however. As the Turkish government began military mobilization (seferberlik), some Armenian men hesitated and even refused to enter military service. Years of Muslim hostility toward their communities had made the Armenians suspect that the mobilization was merely a ploy to remove all able-bodied men from their homes, leaving their families vulnerable to the incessant attacks by çetes (brigands) and armed Kurdish bands.

Contrary to the conventional view that the genocide began in April 1915, violence against Armenians began soon after the outbreak of war, and Armenian ecclesiastical leaders, clearly troubled by the developing crisis but adhering to the conservative disposition of the church, insisted on compliance with government demands so as not to give the authorities the opportunity to exploit refusal to serve in the military, and similar instances of insubordination, as a pretext for atrocities. In September 1914, for instance, about eighty Armenian deserters in the region of Maraş and Zeytun Süleymanlı (the "i" at the end is an-dotted "i" surrendered to the mutassarif (county governor) of Maraş, Ali Haidar Bey, who had little liking for the Armenians. Armenian community leaders, represented by the local primate, Hovhannes Vartabed Karanfilian, were concerned that such tensions could serve as a pretext for the authorities to resort to military measures against Armenians throughout the region. ${ }^{33}$ And, as predicted, Haidar Bey, not satisfied with the number of Armenians who had surrendered to the authorities, urged local Muslims to attack Armenians and ordered the mass arrests of Armenian men. Catholicos Sahag II Khabayan of Cilicia 
vehemently opposed any Armenian involvement in armed conflict with the troops; he encouraged the surrender of escapees and intervened to mediate between the local Armenians and the Turkish authorities. Although, soon thereafter, some of the arrested men were freed, most were sent into exile or executed, the fate of their families left to the whims of the local kaimakam (district governor), Husein Husni. ${ }^{34}$

Conditions were made infinitely worse after Turkey's entry into the war in October and the official proclamation of jihad (holy war) in November. Far from serving as leaders of a theocratic system, the Ittihadists despised religion and religious institutions. As Henry Morgenthau, US ambassador to Constantinople, observes in Ambassador Morgenthau's Story, "Practically all of them were atheists, with no more respect for Mohammedanism than for Christianity, and with them the one motive was cold-blooded, calculating state policy." Referring to Interior Minister Talât, he comments, "I can personally testify that he cared nothing for Mohammedanism for, like most of the leaders of his party, he scoffed at all religions. 'I hate all priests, rabbis, and hodjas,' he once told me-hodja being the nearest equivalent the Mohammedans have for a minister of religion." 35 The Ittihadists, like Sultan Abdul Hamid, employed religion as an instrument of propaganda to mobilize the Muslim masses. The jihad was aimed at the Allies but also at the Armenians. ${ }^{36}$

Beginning in November, government policy became increasingly violent, and the political and economic situation for Armenians across the Armenian provinces and throughout the empire deteriorated rapidly. Çete bands attacked Armenian villages near the city of Sivas and farther north in the region of Şebinkarahisar (ShabinKarahisar). ${ }^{37}$ The newly elected prelate of Sivas, Sahag Odabashian, was killed on his way to Sivas, the murder carried out, it was suspected, with the tacit approval of, if not under direct orders from, the vali (provincial governor), Ahmed Muammer Bey. ${ }^{38}$ On 16 December 1914, an Imperial Rescript nullified the 8 February agreement, ${ }^{39}$ although the German ambassador to Constantinople, Hans von Wangenheim, hoping to improve Armenian perception of German involvement in Turkey, sought to convince Patriarch Zaven that the implementation of the Reform Act would be resumed after the war. $^{40}$

Enver's failed military campaign at Sarıkamış in December 1914 and January 1915 was followed, beginning in February and through the month of March, by the intensification of organized attacks on Armenians. On 2 February 1915, the authorities seized the Monastery of the Holy Cross ${ }^{41}$ near the city of Sivas, and on 18 February, under the pretext of collecting weapons, Turkish soldiers entered Armenian houses, arrested some Armenian leaders, and attacked their families. ${ }^{42}$ In early April, the provinces witnessed the arrest and deportation of Armenian notables in growing numbers, while orders arrived that Armenians must surrender all arms and ammunition, and the arrests, deportations, and massacres escalated by the end of April. ${ }^{43}$

Armenian community leaders, intimately familiar with the Turkish modus operandi in times of political turbulence, appealed to the authorities to end the crisis. Catholicos Sahag pleaded for leniency toward the deserters. Minister of the Marine and Commander of the Fourth Army in Syria, Ahmed Cemal Paşa, replied that the authorities would not harm Armenians loyal to the government. Catholicos Sahag also wrote to vali Celal Bey of Aleppo vilayet regarding the conflict in Zeytun and requested an investigation of the situation. In a letter to Patriarch Zaven, the griefstricken catholicos wrote: "How will this tragedy brough upon the Armenian people in Cilicia be healed? We are told that appeals to Constantinople are useless. ${ }^{44}$ 
On 23 April, a group of Armenian political leaders in Constantinople, including deputies Krikor Zohrab and Vartkes (Hovhannes Serengulian), met with the patriarch to assess the situation and agreed to communicate their concerns to the Sublime Porte. ${ }^{45}$ But on Saturday 24 April, soldiers were stationed throughout Constantinople, home to some 150,000 Armenians, and the authorities arrested about 200 Armenian intellectuals and community leaders, including the renowned musicologist and priest Gomidas Vartabed Soghomonian. These arrestees were exiled to the interior, and an additional 600 people were subsequently arrested. Extensive searches for weapons followed, and within weeks more than 2,300 Armenians had been arrested in Constantinople. Some of them were sent to the predominantly Muslim town of Ayaş, west of Ankara city, and others farther east, to Çankırı and Çorum. ${ }^{46}$

Soon the entire Armenian nation became engulfed in terror, as the Young Turk regime began the deportations while Turks and Kurds attacked Armenian towns. In March, Patriarch Zaven, in a brief but anxious message to Catholicos Sahag, expressed grave concerns about the ominous events unfolding in the empire's Armenian communities. The patriarch appealed to the authorities for a peaceful resolution of the crisis without further bloodshed and requested that the catholicos again petition the Sublime Porte. ${ }^{47}$ In late April 1915, Catholicos Kevork V Surenyants of the Mother See at Echmiadzin sent an urgent telegram to Boghos Nubar, ${ }^{48}$ whom the catholicos had appointed in 1912 to lead the Armenian National Delegation to secure European support in Armenian matters, stating that massacres and "bloody turbulence" had occurred in Erzurum, Bitlis, Van, and Cilicia. The catholicos further informed Boghos Nubar that he had appealed to US President Woodrow Wilson, the Russian Foreign Minister Sergei Sazonov, and King Victor Emmanuel of Italy to use their good offices with Constantinople to find the means to end the persecutions so that at least unarmed civilians could be protected. ${ }^{49}$ Referring to the appeal by the catholicos, US Secretary of State William Jennings Bryan directed Ambassador Morgenthau to call the Sublime Porte's attention to this matter. Interior Minister Talât replied that the Sublime Porte had instructed the authorities in the provinces "to protect all innocent people from molestation." $" 50$

In May 1915, Armenians with no record of political involvement were being arrested in increasing numbers, condemned to hard labor to die of starvation and exhaustion, or else killed soon after their forced deportation. The Armenian prelate of Kayseri, Bishop Khosrov Behrigian, was arrested and handed over to the military courts; subsequently, accused of favoring Russian military liberation of Armenians, he was deported, together with a caravan of hundreds of refugees, and murdered along with several other prominent figures on the road to Diyarbekir. ${ }^{51}$ During the second half of May, 200 Armenians in Yozgat, including businessmen, government officials, intellectuals, and the local primate, Bishop Nerses Tanielian, were arrested, marched out of town, and finally murdered in a valley some distance away. ${ }^{52}$ The prelate of Erzurum, Archbishop Smpad Saadetian, along with a caravan of 7,000 Armenians, was deported to Malatya and met a similar fate in July. ${ }^{53}$

Efforts by Armenian ecclesiastical leaders and their supporters to draw the attention of the Allied Powers to the Armenian crisis seemed to produce a positive result when, on 24 May 1915, Britain, France, and Russia issued a joint declaration stating that they "announce publicly to the Sublime Porte that they will hold all members of the Government, as well as such of their agents as are implicated, personally responsible for such massacres."54 Boghos Nubar intimated to LieutenantColonel G.M. Gregory, president of the United Armenian Association in London, that, 
upon reading the declaration, he was satisfied that "the Allies are taking our cause seriously and are ready to offer us their complete collaboration." 55

Such declarations had little effect on the Ittihadists' decisions regarding the Armenians. In fact, on 29 May 1915, the government instituted the Temporary Law of Deportation, authorizing the military to oversee the wholesale deportation of the Armenian population. ${ }^{56}$ The full ramifications of this law with respect to the Armenian people, but also with respect to the authority of the Armenian Church, were amply clear when Patriarch Zaven went to see Talât Pasha in June to plead for an end to the deportations and killings. The latter refused to see the patriarch and instead responded in a message stating, "Let him say whatever he has to the Minister of Justice; that's the merji'ah [place of authority] where he should go." 57 The patriarch then held a conference with the minister of justice and religious affairs, Pirizade Ibrahim Bey. Their heartrending conversation is worth quoting here:

Patriarch: Several [of] our Nation's Prelates are languishing in jail, and we have no news from the rest. Priests are suffering in jail and at their places of exile. Churches are demolished or locked up, and the people are being pushed toward the desert.

Minister Ibrahim Bey: I have no information about the Prelates being jailed.

Patriarch: Yes, I know for a fact that the Prelates of Gesaria, Brusa, Trebizond, and Dikranagerd have been imprisoned. As for the other Prelates, I do not know what may have happened to them, because I have not received responses to my telegrams .... Now that I do not have my Prelates, priests, or flock, whose spiritual leader am I?

Minister Ibrahim Bey: As Minister of Justice, I accept the petition that you are submitting to me concerning religious matters, but the part in it that pertains to the common people does not fall under my jurisdiction.

Patriarch: A spiritual leader cannot exist without the common people, just like a shepherd cannot exist without his flock, nor an imam [Muslim priest] without his jemaat [believers]. It is only natural that I should come to inquire of you as to the whereabouts of my people, so that I might take care of their needs. When my people are uprooted and driven toward the mountain and the desert, how can I be their leader any more?

Minister Ibrahim Bey: Do not say, “They are driven!" Yet, more as a friend than as an official, I assure you that the government has made and is making all the arrangements for their comfort. ${ }^{58}$

During a meeting with Grand Vizier Salim Pasha, Patriarch Zaven pleaded, "The exceptional situation in which my Nation finds itself compels me to ask for the State's mercy." Salim replied that the government, although confronted with a "structured organization" and a segment of the population that "has taken up arms against us," did not intend to annihilate the Armenians but, rather, was "implementing a tedbir [precautionary measure] and...removing the Armenians from those Provinces." The grand vizier commented that this policy was "not a jeza" (i.e., not a punishment). The patriarch countered that it was a "big jeza, and it is not even proportionate [to] the imputed crimes!" His flock, now composed mostly of women and children, was being deported to the mountains and the desert. "What will happen to them? May God have pity on them!" The grand vizier inquired, "Talaata getmedin mi?" (Did you not go to Talât?). When the patriarch replied that Talât had refused to see him, the grand vizier concluded the conversation thus: "Bunlar olmamalı idi!" (These should not have happened). ${ }^{59}$

Unable to move the Young Turk leaders to terminate the deportations and the bloodshed, Armenian Church leaders intensified their appeals to the Western powers 
and to world public opinion. Patriarch Zaven wrote to the prelate of the Armenian Church in Bulgaria, Bishop Ghevont Turian, with appeals to disseminate information about the atrocities being committed by the Young Turk regime against the Armenians. ${ }^{60}$ In a number of letters the patriarch implored Bishop Turian to "find a remedy to this frightful situation" by convincing the Allied Powers to put pressure on the Young Turk regime to stop further persecution and murder of the Armenians. ${ }^{61}$ The patriarch informed Turian:

One after the other, populations from Samson and Gesaria all the way to and including Dikranagerd and Edessa [Urfa] have been put on the road. The Armenian populations of Trebizond, Sepasdia, Kharpert, Paghesh, Van, and Dikranagerd, from the oldest to the youngest and excepting not a single person, have been driven to the deserts of Mesopotamia-from areas south of Aleppo to Mosul and Baghdad. ${ }^{62}$

In July 1915, Catholicos Kevork V of the Mother See at Echmiadzin appealed to President Wilson to find a means "in the name of humanity and our holy Christian faith" to intervene to end the atrocities and massacres. ${ }^{63} \mathrm{He}$ also advised his envoy in London, Boghos Nubar, "to protest to the Allies and the neutral states" and to appeal for the prevention of further deportations and annihilation of the Armenians. ${ }^{64}$ Boghos Nubar, for his part, informed Bighop Turian that "unfortunately, the authorities [of the United States and Italy] have not succeeded in persuading the Sublime Porte to change its policy toward the Armenians. As Your Eminence had mentioned in the report, this policy aims at the annihilation of the Armenian nation. Thus, in spite of these appeals, the persecutions have continued." 65 Several weeks later, Catholicos Kevork V sent another appeal to the Western powers to intervene-but to no avail. ${ }^{66}$ On 26 September 1915, the Ittihadists promulgated the Temporary Law on Expropriation and Confiscation, permitting the government to seize the goods and properties of the deported. ${ }^{67}$ In December, Count Paul Wolff-Metternich, Ambassador Wangenheim's successor in Constantinople, commented in a telegram to Berlin that "protests are useless and Turkish denials that no more deportations are to be undertaken are worthless." 68

By the end of 1915, most of the Armenians had been deported from their ancestral homeland, with only a handful of locations evincing sufficient capability to demonstrate resistance. These included Van, Şebinkarahisar, Şanlıurfa, Zeytun, Bitlis, and Musa Dagh, the last immortalized by Franz Werfel's The Forty Days of Musa Dagh. ${ }^{69}$ Most of the local Armenian priests were imprisoned and murdered or, if left alive, deported; some of them chose to depart from the customary orientation of the patriarchate and took part in local resistance movements. In a letter to Catholicos Kevork V, Father Vartan Varteresian, who for years had served as the local priest at Suedia, noted that four other local priests had participated in the resistance at Musa Dagh. ${ }^{70}$

The genocidal policies of the Young Turk regime entered a new phase as the Ittihadists sought to liquidate the Armenian Church. In December, Talât sent an urgent telegram to authorities in Aleppo vilayet instructing that those Armenian clergy who had been able to reach Syria and Jerusalem be annihilated. ${ }^{71}$ Indeed, as Morgenthau states in his Story,

Nothing was sacred to the Turkish gendarmes; under the plea of searching for hidden arms, they ransacked churches, treated the altars and sacred utensils with the utmost indignity, and even held mock ceremonies in imitation of the Christian sacraments. They would beat the priests into insensibility, under the pretense that they were the centres of sedition. When they could discover no weapons in the churches, they would 
sometimes arm the bishops and priests with guns, pistols and swords, then try them before courts-martial for possessing weapons against the law, and march them in this condition through the streets, merely to arouse the fanatical wrath of the mobs. ${ }^{72}$

\section{The Abolition of the Armenian Church $^{73}$}

In early 1916 the central government informed the Armenian Patriarchate in Constantinople and the Catholicosate at Sis of their intention to terminate both institutions. Now that nearly the entire Armenian population had been removed from their homeland, the services of the patriarchate as the representative of the Armenian millet were no longer needed. In January 1916, the patriarch was notified of the Ittihadist government's intention to nullify the Armenian National Constitution, and on 28 July/10 August of the same year the government abolished the Patriarchate in Constantinople and the Catholicosate of Aghtamar, ordering the virtually defunct Catholicosate of Aghtamar to be combined with the patriarchates in Jerusalem and Constantinople. It further ordered the Catholicosate of Sis to remain permanently in Jerusalem and to assume the title of Catholicos-Patriarch. ${ }^{74}$ The Ministry of Justice and Religion submitted a statement to the Armenian Patriarchate announcing the abolition of his authority. Addressed to Patriarch Zaven, the communication concluded: "Your position and the structure of the Armenian Patriarchate have come to an end." 75 The government also ordered the patriarch to move to Baghdad and thence to Mosul, where he remained until the conclusion of the war. The seminarians at the Armash Seminary were ordered to Jerusalem or else-very much like their compatriots-were dispersed, exiled, and murdered. ${ }^{76}$ Former patriarch Ormanian was deported to Damascus in $1917 .{ }^{77}$ Harry Stuermer, wartime correspondent for the Kölnische Zeitung in Constantinople, commented that

by dissolving the Patriarchate in the Capital, breaking off all relations with the Armenian headquarters in Etzmiadjin and allowing only a very small remainder of Patriarchate to be sent up in Jerusalem under special state supervision, the Turks, as a logical sequence to the Armenian atrocities, simply dealt a death-blow in the summer of 1916 to this important social institution. ${ }^{78}$

In the meantime, Catholicos Sahag, who had been exiled to Aleppo in late 1915, was notified by Cemal Paşa of the decision regarding the restructuring of the Armenian Church. In so doing, the government limited what little legal protection and privileges the Armenian Church had retained during the preceding years. Immediately after Catholicos Sahag arrived at Aleppo, however, the authorities demanded that he take up residence at the Patriarchate in Jerusalem, where he remained, at the St. James Monastery, until the end of August 1916. In one of his reports to the Armenian patriarchate, Catholicos Sahag describes the conditions there:

The road from Aleppo to Damascus was lined with thousands of Armenian refugees. Some were living in tents and others in the open air, begging for bread and water and asking for news about their friends. We went through places where one tenekeh [tin can] of water cost six to seven piasters, but still there was no one to give it. Many refugees-no one knows the exact number-are in the area of Kerek, and in the district of Salt there are about 400 households. Every village has 100 households of refugees, and in the sanjak of Serai there are approximately 500 households. These people come to the monastery, where they receive 30 to 40 loaves of bread a day, which [they] eat in the kitchen. About 80 refugees from Adana-with the special favor of Jemal Pasha-have arrived in Jerusalem and are living in the monastery compound. 
There are also many soldiers with their families. Every day, two or three Armenian amele [laborers] die. ${ }^{79}$

Catholicos Sahag also lamented the restructuring of the Armenian Church: "I suppose I am to be congratulated for the honor bestowed upon me as the Catholicos-Patriarch of Cilicia, Constantinople, and Jerusalem. This restructuring is nothing but the destruction of our historic Church, our spiritual center, the heart and soul of our people." 80

The deportation of Patriarch Zaven and Catholicos Sahag of Cilicia left only Catholicos Kevork V of Echmiadzin, among the ecclesiastical leaders, to pursue matters with the Western governments. After several entreaties to the latter for some form of intervention, Catholicos Kevork had, during 1915 and 1916, come to accept the fate of his compatriots across the Ottoman border. He was encouraged, however, based on communications from his envoy Boghos Nubar, that after the war the Allied Powers would provide the necessary support for an Armenian homeland free of Turkish rule. As early as 28 July 1915, Boghos Nubar reported that, having visited several high-ranking officials in London, he was pleased that "the British government will graciously agree to support our national cause until its accomplishment, when the time will come to decide the fate of the Ottoman Empire, after the victory of the Allies." Boghos Nubar expressed confidence that his "negotiations have been quite fruitful, and Russia, France, and England show a friendly disposition toward our cause." His next letter reiterates this point: "We can rest assured that after the final victory of the Allies, we shall have the benefit of their support to accomplish our plan." 81

While in February 1916, as a result of the Russian capture of Erzurum, Boghos Nubar urged Catholicos Kevork V to maintain close relations with the czarist government as the only reliable ally with "favorable inclination and unanimous feelings" toward the Armenian Question, the Sykes-Picot Agreement signed by the Allied Powers in April shifted Boghos Nubar's attention to British and French postwar aims and, particularly, French aspirations concerning Cilicia. ${ }^{82}$ It was ironic at best that Boghos Nubar, serving as the personal envoy of the catholicos at Echmiadzin, would insist on including Cilicia as part of the envisioned Armenian homeland, when in fact the catholicos, in his capacity, could have exerted little influence in matters pertaining to the region. The catholicos sought to maintain close relations with Russia's provisional government after the revolution that overthrew the czarist government in February 1917, but hopes for Russian engagement to provide protection for Armenian refugees began to dissipate after the Bolshevik revolution in October-November $1917 .{ }^{83}$

Nevertheless, despite the calamitous events since 1914, what inspired most hope was the reestablishment, in May 1918, of an Armenian government in the Caucasus, with the city of Yerevan, about thirteen miles from Echmiadzin, as its capital. The last Armenian government in the region, the Bagratuni kingdom, had been destroyed by the Seljuk invasions in the eleventh century. The Allied victory and occupation of Constantinople and parts of the interior gave rise to expectations that the promises (such as the 24 May joint declaration) expressed during the war, when there was no Armenian government, would surely be realized now that a sovereign Armenian government had formal representation before the victors. Yet, as General Kress von Kressenstein, head of the German delegation in the Caucasus, reported to the German foreign ministry in August 1918, the deplorable conditions across the Republic of Armenia, where thousands of refugees were living in chaos and starving to death, rendered political and economic normalcy utterly inaccessible to both the government 
in Yerevan and the Catholicosate at Echmiadzin. ${ }^{84}$ With respect to the role of the Armenian Church, the Allied victory redirected international attention from the Catholicosate at Echmiadzin as the center of Armenian ecclesiastical authority to the Patriarchate in Constantinople and the Catholicosate of Sis as some of the survivors began their long-awaited return to the homeland.

\section{Reinstitution of the Armenian Church after the War}

Immediately after the Mudros Armistice of 30 October 1918, the defeated Turkish government, on 4 November, repealed the Temporary Law of Deportation, ${ }^{85}$ and on 20 November the legal status of the Armenian Patriarchate was restored according to the National Constitution of 1863. The government also reinstituted the Catholicosate of Cilicia at Sis, although it was to retain the title assigned under the 1916 decree of Catholicos-Patriarch. ${ }^{86}$ Patriarch Zaven, known for his pro-British orientation, returned to Constantinople on the British destroyer Acacia on 19 February 1919. ${ }^{87}$

Upon resuming his post on 20 February 1919, the patriarch oversaw the reorganization of the ecclesiastical and secular structures of administration, consisting of the National General Assembly and administrative assemblies. Thereafter, the patriarchate and the associated organizations in Constantinople instituted a number of social services, most prominently to care for the orphans of the massacres. They established the Orphan Collection Agency, the Orphan Care Agency, and the Society for Deportees; the latter two merged on 28 February 1919 to form the Armenian National Trusteeship. ${ }^{88}$ The National Trusteeship supervised several orphanages and relocation posts, including, for example, the Beylerbey Orphanage and the Beşiktaş Orphanage for Girls. Armenian compatriotic societies contributed to their efforts. Armenians from Kayseri, for example, established the Compatriotic Society of Kayseri Natives, ${ }^{89}$ which organized efforts to gather and care for the orphans from the region. The National Assembly introduced a "fatherland tax" to meet the financial needs of the orphans. By December 1922, about 3,000 Armenian orphans had been rescued, of an estimated 4,000 to 5,000 in Constantinople alone. A large number of them emigrated to Europe, the United States, and Canada. In Cilicia, Syria, Lebanon, and Armenia, tens of thousands of orphans remained in need of care in several orphanages, as in Adana, Maraş, Aleppo, Juné, and Gumri. ${ }^{90}$ The Mother See at Echmiadzin, in cooperation with the nascent government, spearheaded the relief effort for the refugees in Gumri, in Yerevan, and across Armenia, but the post-World War I military, economic, and political chaos plaguing the Caucasus undermined all such efforts. ${ }^{91}$

In a letter to Catholicos Kevork V in May 1919, Patriarch Zaven listed the names of twenty-five prelates of the Armenian Apostolic Church who had been imprisoned, tortured, and murdered. Among them were some of the brightest leaders of the Armenian Church in the early twentieth century, including Bishop Smpad Saadetian, prelate of Erzurum; Bishop Khosrov Behrigian, prelate of Kayseri; and Bishop Nerses Tanielian, prelate of Yozgat. Patriarch Zaven added that as of yet it would be impossible to prepare a complete list of the clergy who had perished during the genocide, but he estimated that the total number of Armenian lives lost exceeded 1.25 million. The primary task now was to marshal the financial, human, and organizational resources of Armenian communities to coordinate the revival of Armenian spiritual, cultural, educational, economic, and political life-the very life that the Young Turks had sought to destroy. ${ }^{92}$

Having resumed his post, Catholicos Sahag began the task of reorganizing the Armenian community in Cilicia as thousands of refugees began their homeward 
journey. In January 1919, he communicated to British General Sir Edmund H.H. Allenby, then British high commissioner for Egypt and Sudan, the urgent need to disarm the Muslim population in Cilicia, as the repatriating Armenians feared a recurrence of wholesale massacres. The catholicos warned that since the architects of the genocide had thus far gone unpunished, while the repatriating Armenians were reclaiming their properties, renewed bloodshed appeared inevitable. ${ }^{93}$ Despite such warnings, the Allied Powers did little to prevent further Armenian calamities. Instead, as the catholicos observed in a letter to Boghos Nubar, the Allies allowed Patriarch Zaven to return to Constantinople merely to be employed in collecting relief funds. ${ }^{94}$

Repatriation of Armenian refugees from northern Syria began in the summer of 1919, and by early 1920 thousands of Armenians had repatriated to the region of Cilicia. Armenian life appeared to be on the road to revival as the Armenian Apostolic, Protestant, and Catholic churches and various organizations, schools, and orphanages resumed their community activities and served the repatriates. ${ }^{95}$ The Catholicosate of Cilicia directed the organizational life of several orphanages, the largest concentrations being in Adana, Aintab, and Aleppo. In September 1919, Catholicos Sahag returned to Adana and then to Sis to begin the process of reconstruction. Beginning in March 1920, he traveled to France, England, and Italy to present the Armenian case before the victorious Allied Powers, but by the time he returned to Adana in November, a series of peace treaties-the Treaty of London (19 March 1920), the Treaty of San Remo (18 May 1920), and the Treaty of Sèvres (10 August 1920)—had so altered the geopolitical situation in Turkey and the Middle East as to render his mission superfluous. The conferences in European capitals produced much praise for the Armenians and the Cilician catholicos but little concrete support for the Armenians. The Kemalist movement and the French refusal to support Cilician Armenians led to the final destruction of the Cilician Catholicosate in Sis by the end of 1921. Catholicos Sahag departed from Cilicia for the last time on 25 November 1921, a month after the signing of the Franco-Turkish treaty (the Treaty of Ankara, 20 October 1921) that recognized the Kemalist government at Ankara. ${ }^{96}$ By then, thousands of Muslim muhajirs (refugees) arriving to Cilicia from different parts of the empire had seized Armenian homes, and the seminary of the catholicosate in Sis had been converted into a school for the children of the muhajirs.

\section{The Catholicosate of Cilicia in Exile}

For several years, the Catholicosate of Cilicia lacked its own institutional base. ${ }^{97}$ The ancient city of Aleppo, which had historically been one of the major dioceses of the Cilician Catholicosate, at first appeared to be the principal candidate for the postgenocide seat. After the removal of the Catholicosate from Sis and the total deportation and massacres of the Armenians across Cilicia, a considerable proportion of the refugees arriving from Cilicia and the eastern provinces were in northern Syria, and the city of Aleppo could play a central role in the organization of relief activities. The prelacy at Aleppo was already representing the Armenian refugees in official matters regarding relief funds and directing several committees engaged in the distribution of goods. ${ }^{98}$ But it would be some years before the Armenian Church could recover from the destruction suffered during the genocide.

According to the statistics kept by the Patriarchate in Constantinople, prior to World War I there were 3,788 churches and 3,909 parishes in Ottoman and Russian Armenia. 99 Four decades later, as Table 1 shows, there was a total of 417 churches and 446 parishes. ${ }^{100}$ Whereas before World War I there were 2,138 
Table 1: Statistics on Armenian apostolic dioceses

\begin{tabular}{lccccr}
\hline & \multicolumn{2}{c}{ Before World War I } & & \multicolumn{2}{l}{1954} \\
\cline { 2 - 3 } & Churches & Parishes & & Churches & Parishes \\
\hline Patriarchate of Constantinople & 1,634 & 1,778 & & 38 & 42 \\
Catholicosate of Echmiadzin & 1,650 & 1,660 & & 330 & 354 \\
Catholicosate of Cilicia & 214 & 267 & & 40 & 45 \\
Patriarchate of Jerusalem & 18 & 10 & & 9 & 5 \\
Catholicosate of Aghtamar & 272 & 194 & & 0 & 0 \\
Total & $\mathbf{3 , 7 8 8}$ & $\mathbf{3 , 9 0 9}$ & & $\mathbf{4 1 7}$ & $\mathbf{4 4 6}$ \\
Total in the Ottoman Empire & 2,138 & 2,249 & & - & - \\
Total in the Republic of Turkey & - & - & & 38 & 42 \\
\hline
\end{tabular}

Source: Maghakia Ormanian, The Church of Armenia, trans. G. Marcar Gregory, 3rd rev. ed. (New York: St. Vartan Press, 1988), appendices II and III, 239-45.

churches in the Ottoman Empire, the figure had dropped to thirty-eight by 1954 . Equally significant, while prior to the genocide all of the Cilician churches were located in Cilicia, their number not only declined from 214 to forty as a result of the genocide, but all of them were found in foreign lands, in diasporan communities hundreds, if not thousands, of miles from the homeland. The historic Catholicosate of Cilicia at Sis, once the Holy See within a thriving Armenian kingdom, had witnessed a dramatic diminution in its authority and jurisdiction under Ottoman tutelage and was, in the end, completely destroyed under the Young Turk regime. So too did the Catholicosate of Aghtamar, with its once thriving parishes along the Lake Van basin, perish during the genocide.

To be sure, the destruction of the Armenian churches during and since the genocide was representative of the Turkish drive first to annihilate the Armenian people and then to eradicate all memories of its existence across the ancient Armenian homeland. Having nearly accomplished the first objective, the Turkish government has been engaged in a campaign of denial and eradication since the establishment of the Kemalist regime in 1923. Referring to similar comparative data, Karekin Vartabed Sarkissian-then the dean of the Armenian Theological Seminary at Antelias, Lebanon, later Catholicos of Cilicia at Antelias, and subsequently Catholicos of All Armenians at Echmiadzin—has put it most aptly: "The simple comparison is more eloquent about the consequences of the massacres than any comment made by the most highly gifted historian."101

Despite the devastation, the Armenian Church has remained the principal institution in perpetuating the memory of the nation's martyrdom; for the past nine decades, the church has led the commemoration of the genocide. On 24 April 1919, the reinstituted Patriarchate in Constantinople for the first time organized a commemorative event. ${ }^{102}$ The following year, author, literary critic, and historian Vrtanes Papazian, who at the time served as principal of the secondary school in Echmiadzin, encouraged Catholicos Kevork V to issue a declaration proclaiming 24 April as a day of national mourning. ${ }^{103}$ Since then, the Armenian Church has organized, or co-sponsored with community organizations throughout the diaspora and in Armenia, commemorations of the genocide. 


\section{Acknowledgments}

I would like to thank the anonymous reviewers of Genocide Studies and Prevention for their useful comments.

An earlier draft of this paper was presented at the International Conference on the Christian Response to Violence, organized by the Western Prelacy of the Armenian Apostolic Church of America, in collaboration with the Institute of Armenian Studies at the University of Southern California and the USC Center for Religion and Civic Culture, Los Angeles, CA, 15 October 2005.

\section{Notes}

1. G. Marcar Gregory, Preface, in The Church of Armenia, by Maghakia Ormanian, trans. G. Marcar Gregory, 3rd rev. ed. (New York: St. Vartan Press, 1988), viii.

2. The current Turkish name is Kozan.

3. For useful historical background on the Armenian Church, see Ormanian, The Church of Armenia, 3-94; K.V. Sarkissian, "The Armenian Church," in Religion in the Middle East: Three Religions in Concord and Conflict, vol. 1, Judaism and Christianity, ed. A.J. Arberry (Cambridge: Cambridge University Press, 1969): 482-520; F.M. Pareja, "Society and Politics," in Religion in the Middle East: Three Religions in Concord and Conflict, vol. 2, Islam, ed. A.J. Arberry (Cambridge: Cambridge University Press, 1969): 492-500; Avedis K.Sanjian, The Armenian Communities in Syria under Ottoman Dominion (Cambridge, MA: Harvard University Press, 1965), Ch.5, 95-141.

4. Vahakn N. Dadrian, The History of the Armenian Genocide: Ethnic Conflict from the Balkans to Anatolia to the Caucasus (Providence, RI: Berghahn Books, 1995), 4-6.

5. Hagop Barsoumian, "The Eastern Question and the Tanzimat Era," in The Armenian People from Ancient to Modern Times, vol. 2, Foreign Dominion to Statehood: The Fifteenth Century to the Twentieth Century, ed. Richard G. Hovannisian, 175-201 (New York: St. Martin's Press, 1997), 184.

6. Ibid., 180-84.

7. Maghakia Ormanian, Azkabadum [History of the Nation], vol. 3 (Jerusalem: St. James Press, 1927; reprint, Antelias: Catholicosate of Cilicia, 2001), col. 4068.

8. Barsoumian, "Eastern Question," 199-200; Richard G. Hovannisian, "The Armenian Question in the Ottoman Empire, 1876-1914," in The Armenian People from Ancient to Modern Times, vol. 2, Foreign Dominion to Statehood: The Fifteenth Century to the Twentieth Century, ed. Richard G. Hovannisian, 203-38 (New York: St. Martin's Press, 1997), 203; Christopher J. Walker, Armenia: The Survival of a Nation (New York: St. Martin's Press, 1980), 100-102, 108-17; Louise Nalbandian, The Armenian Revolutionary Movement: The Development of Armenian Political Parties through the Nineteenth Century (Berkeley and Los Angeles: University of California Press, 1963), 74-78, 80-85.

9. See also George A. Bournoutian, "The Ethnic Composition and the Socio-Economic Condition of Eastern Armenia in the First Half of the Nineteenth Century," in Transcaucasia, Nationalism, and Social Change: Essays in the History of Armenia, Azerbaijan, and Georgia, rev. ed. by Ronald Grigor Suny, 69-86 (Ann Arbor: University of Michigan Press, 1996), 79; Ronald Grigor Suny, "Eastern Armenians under Tsarist Rule," in The Armenian People from Ancient to Modern Times, vol. 2, Foreign Dominion to Statehood: The Fifteenth Century to the Twentieth Century, ed. Richard G. Hovannisian, 109-37 (New York: St. Martin's Press, 1997), 113-15.

10. V.A. Tiloyan and V.H. Rshduni, "Arevelian Hayasdane Rusasdani gazmum [Eastern Armenia in the Russian System]," in Hay zhoghovrti badmutyun, vol. 5, ed. Ts.P. Aghayan et al., 201-53 (Yerevan: Armenian Academy of Sciences, 1974), 214; Ormanian, Azkabadum, vol. 3, cols. 5156-59.

11. Hovannisian, "Armenian Question," 206-209. 
12. Ibid., 207-208; Suny, "Eastern Armenians," 127; Walker, Armenia, 108-10.

13. Hovannisian, "Armenian Question," 208-10; Suny, "Eastern Armenians," 127.

14. Hovannisian, "Armenian Question," 210, 211; Walker, Armenia, 117.

15. M.G. Nersissyan, Hay zhoghovrti azadakragan baykare Turkagan prnabedutian tem, 1850-1870 [The Armenian People's Struggle for Liberation against Turkish Tyrannical Rule, 1850-1870] (Yerevan: Armenian Academy of Sciences, 1955); Anahide Ter Minassian, Nationalism and Socialism in the Armenian Revolutionary Movement (1887-1912) (Cambridge, MA: Zoryan Institute, 1984); Nalbandian, Armenian Revolutionary Movement, 67-178.

16. Ormanian, Azkabadum, cols. 5058-61; Barsoumian, "Eastern Question," 188; Mesrob K. Krikorian, Armenians in the Service of the Ottoman Empire, 1860-1908 (London: Routledge, 1977). For a particularly revealing opinion on Armenian revolutionary activities, see Bibliothèque Nubar (Paris), Doc. 991-998, comments by Boghos Nubar in an undelivered letter to Catholicos Sahag of Cilicia, 17/30 April 1915, in Boghos Nubar's Papers and the Armenian Question, 1915-1918, ed. and trans. Vatche Ghazarian (Waltham, MA: Mayrnei Publishing, 1996), 14 [Boghos Nubar's Papers].

17. Hovannisian, "Armenian Question," 212, 217.

18. Ibid., 219-20; Ormanian, Azkabadum, cols. 5027-30; Richard G. Hovannisian, "The Historical Dimensions of the Armenian Question, 1878-1923," in The Armenian Genocide in Perspective, ed. Richard G. Hovannisian, 19-41 (New Brunswick, NJ: Transaction Books, 1986), 19-26; Walker, Armenia, 136-42, 156-64; Christopher Walker, "From Sassun to the Ottoman Bank: Turkish Armenians in the 1890s," Armenian Review 30 (March 1979): 227-64; Armen Garo, "Abrvadz orer [Days Lived]," Hairenik amsakir 1:9 (July 1923): 94.

19. Johannes Lepsius, Armenia and Europe: An Indictment, ed. and trans. J. Rendel Harris (London: Hodder and Stoughton, 1897), 20, 21-24, 47, 49-51, 330-31.

20. Ormanian, Azkabadum, cols. 5006-10, 5016-20, 5058-61.

21. Ibid., cols. 5040-42, 5058-61.

22. For Ormanian's criticism of Izmirlian and the Armenian nationalist movements, see ibid., cols. 5016-20, 5058-61; Ormanian, Church of Armenia, 205-208. See also Pareja, "Society and Politics," 495; Walker, Armenia, 408-409.

23. Şerif Mardin, The Genesis of Young Ottoman Thought (Princeton, NJ: Princeton University Press, 1962); Şerif Mardin, Jön Türklerin Siyasi Fikirleri, 1895-1908 (İstanbul: İletișim Yayınları, 1983); M. Şükrü Hanioğlu, The Young Turks in Opposition (New York: Oxford University Press, 1995).

24. From Annual Report for Turkey for the Year 1908, encl., dispatch from Sir Gerard Lowther, no. 105, Feb. 17, 1908, R., Feb. 22, 1909, in British Documents on the Origins of the War, 1898-1914, vol. 5, The Near East, ed. G.P. Gooch and Harold Temperely (London: HMSO, 1928), 304-305. See also Dadrian, History of the Armenian Genocide, 43; Hovannisian, "Armenian Question," 228-30.

25. Ormanian, Azkabadum, cols. 5395-99.

26. Hovannisian, “Armenian Question," 230-32.

27. Ormanian, Azkabadum, cols. 5435-37.

28. See Feroz Ahmad, The Young Turks: The Committee of Union and Progress in Turkish Politics, 1908-1914 (Oxford: Clarendon Press, 1969); Bernard Lewis, The Emergence of Modern Turkey (London: Oxford University Press, 1961); Jacob M. Landau, Pan-Turkism: From Irredentism to Cooperation, 2nd ed. (Bloomington: Indiana University Press, 1995).

29. Christopher Walker, "World War I and the Armenian Genocide," in The Armenian People from Ancient to Modern Times, vol. 2, Foreign Dominion to Statehood: The Fifteenth Century to the Twentieth Century, ed. Richard G. Hovannisian, 239-73 (New York: St. Martin's Press, 1997), 242.

30. Ormanian, Church of Armenia, 226. 
31. Zaven Der Yeghiayan, My Patriarchal Memoirs, trans. Ared Misirliyan, ed. Vatche Ghazarian (Barrington, RI: Mayreni Publishing, 2002), 8. The original Armenian edition was published in Cairo by Nor Asdgh in 1947.

32. Richard G. Hovannisian, Armenia on the Road to Independence, 1918 (Berkeley and Los Angeles: University of California Press, 1967), 38-39; Simon Vratzian, Hayasdani Hanrabedutiun [Republic of Armenia] (Paris: A.R.F. Central Committee of America, 1928; reprint, Yerevan: Hayasdan, 1993), 5-6. See also the report by Nikoghayos Adontz on the activities of the National Assembly, the National Executive, and the Security Committee in Constantinople. Nikoghayos Adontz, "Haygagan hartsi shurch Turkiayum [Concerning the Armenian Question in Turkey]," trans. Valder Tiloyan, in Haygagan harts [The Armenian Question], by Nikoghayos Adontz, comp. Bedros Hovhannisyan et al., 25-48 (Yerevan: Hayakidag, 1996).

33. Khoren K. Davidson, Odyssey of an Armenian of Zeitoun (New York: Vantage Press, 1985), 56; Krikor H. Kalustian, comp. and ed., Marash gam Kermanig ev heros Zeytun [Marash or Germanica and Heroic Zeytun], 2nd ed. (Long Island City, NY: Union of Marash Armenians, 1988), 176. Johannes Lepsius concurred that the government was searching for a pretext to intervene. See Johannes Lepsius, Rapport secret sur les massacres d’Arménie (Paris: Payot, 1918; reprint, Beirut: Hamazkayin Press, 1980), 27. See also Germany, Politisches Archiv des Auswärtigen Amts (PA-AA), Embassy Constantinople, vol. 168, Vice Consul Hoffmann, Alexandretta, to German Ambassador Wangenheim, Constantinople, March 7, 1915, Doc. 18, in Deutschland und Armenien, 1914-1918: Sammlung Diplomatischer Aktenstücke, by Johannes Lepsius, 31-32 (Potsdam: Tempelverlag, 1919); an English translation by Linda Struck appears in The Armenian Genocide during the First World War: Documents from German State Archives, ed. Wolfgang and Sigrid Gust, http://www.armenocide.de (accessed 6 July 2006).

34. Archives of the Catholicosate of Cilicia, Doc. 4536/325, Catholicos Sahag of Cilicia to Bishop Kud, 25 September 1914; Doc. 4536/326, Catholicos Sahag of Cilicia to Patriarch Zaven, 27 September 1914, both in Giligian gsgidzner: Vaverakrer Giligioy gatoghigosagan tivanen, 1903-1915 [Cilician Pains: Documents from the Archives of the Cilician Catholicosate], comp. Zakaria Bzdigian, 110-15 (Beirut: Hrazdan, 1927); Puzant Yeghiayan, Zhamanagagits badmutyun gatoghigosutyan hayots Giligioy, 1914-1972 [Contemporary History of the Armenian Catholicosate of Cilicia, 1914-1972] (Antelias: Catholicosate of Cilicia Press, 1975), 39-42; Arnold Toynbee, comp. and ed., The Treatment of Armenians in the Ottoman Empire, 1915-16: Documents Presented to Viscount Grey of Fallodon, Secretary of State for Foreign Affairs, Miscellaneous no. 31, 1916, 3rd ed. (London: Sir Joseph Causton and Sons, 1916; reprint, Beirut: G. Doniguian and Sons, 1988), 479-81, Doc. 122; Levon Norashkharian, Zeytune, 1914-1921 tt. [Zeytun, 1914-1921] (Yerevan: Armenian Academy of Sciences, 1984), 10-11; Haigaz M. Boghosyan, Zeytuni badmutyune, 1409-1921 tt. [The History of Zeytun, 1409-1921] (Yerevan: Hayasdan, 1969), 384-86.

35. Henry Morgenthau, Ambassador Morgenthau's Story (New York: Doubleday, 1918), 20,323 .

36. Dadrian, History of the Armenian Genocide, 4-5, 240.

37. Haigazn Ghazarian, Tseghasban Turke [The Genocidal Turk] (Beirut: Hamazkayin Press, 1968), 91-92, 116.

38. Der Yeghiayan, Memoirs, 54-55; Toynbee, Treatment of Armenians, Doc. 82; Levon Chormisian, Hamabadger arevmdahay meg taru badmutyan [A Panorama of One Century of Western Armenian History], vol. 3 (Beirut: Sevan, 1975), 451; Sebuh Aguni, Milion me hayeru charti badmutyune [The Story of the Massacre of a Million Armenians] (Constantinople: Hayasdan, 1921), 76.

39. Dadrian, History of the Armenian Genocide, 212. On the Ittihadist reaction to the February Agreement, see Djemal Pasha, Memories of a Turkish Statesman, 1913-1919 (New York: George H. Doran, 1922), 262-76.

40. Germany PA-AA, R14085, Wangenheim to Kaiserlich, Deutsche Botschaft, 29 December 1914, in Deutschland und Armenien, 1914-1918: Sammlung Diplomatischer Aktenstücke, 
by Johannes Lepsius, 23-24 (Potsdam: Tempelverlag, 1919), Doc. 13. An English translation by Linda Struck appears in Gust and Gust, The Armenian Genocide.

41. In Armenian, the Monastery of Surp Nshan.

42. Ghazarian, Tseghasban Turke, 92, 176.

43. US National Archives, Record Group [RG] 59, 867.4016/288, Philip Hoffman to Secretary of State, 12 June 1916, encl., report by Dr. C.E. Clark, 31 May 1916; Aguni, Milion, 266; Lepsius, Rapport secret, 44-45; Nazaret Piranian, Kharperti Yegherne [The Genocide in Kharpert] (Boston: Baikar, 1937), 99; Asadur H. Magarian, "Ampop hamaynabadger [Concise Overview]," in Hushamadyan Medz Yegherni, 1915-1965 [Memorial Volume of the Colossal Crime, 1915-1965], comp. and ed. Kersam Aharonian (Beirut: Atlas, 1965): 309.

44. Archives of the Catholicosate of Cilicia, Doc. 4980/73, Catholicos Sahag of Cilicia to Patriarch Zaven, 7 April 1915, in Giligian gsgidzner: Vaverakrer Giligioy gatoghigosagan tivanen, 1903-1915 [Cilician Pains: Documents from the Archives of the Cilician Catholicosate], comp. Zakaria Bzdigian, 144-45 (Beirut: Hrazdan, 1927).

45. Der Yeghiayan, Memoirs, 62-63; Germany, PA-AA, Embassy Constantinople, vol. 168, Consul General Mordtmann, 26 April 1915, in Deutschland und Armenien, 1914-1918: Sammlung Diplomatischer Aktenstücke, by Johannes Lepsius, 51-52 (Potsdam: Tempelverlag, 1919), Doc. 13. An English translation by Linda Struck appears in Gust and Gust, The Armenian Genocide.

46. Krikoris Balakian, Hay koghkotan [The Armenian Calvary] (Yerevan: Hayasdan, 1991), 46-109; Henry Barby, Au pays de l'épouvante: l'Arménie martyre (1917; reprint, Beirut: Edition Hamazkayin, Association Culturelle Arménienne, 1972), 56; Lepsius, Rapport secret, 48, 228-29, 231, 233-34; Dadrian, History of the Armenian Genocide, 221.

47. Der Yeghiayan to Catholicos Sahag, 21 March 1915, in Giligian gsgidzner: Vaverakrer Giligioy gatoghigosagan tivanen, 1903-1915 [Cilician Pains: Documents from the Archives of the Cilician Catholicosate], comp. Zakaria Bzdigian (Beirut: Hrazdan, 1927): 140.

48. Boghos Nubar (1851-1930) was the son of Nubar Pasha (1825-1899), who had served as prime minister of Egypt. For a succinct background on Boghos Nubar and the Armenian National Delegation, see Boghos Nubar's Papers, xvii-xxxiii.

49. France, Archives du Ministère des Affaires Étrangères (A.M.A.E.), Guerre 1914-1918, Turquie, Kévork V, Catholicos de tous les Arméniens, à Sa Majesté Victor-Emmanuel, Roi d'Italie, 22 April 1915, in Les grandes puissances: l'empire ottoman et les arméniens dans les archives françaises (1914-1918), ed. and comp. Arthur Beylerian (Paris: PanthéonSorbonne, 1983), 14; Catholicos Kevork V to Boghos Nubar, 22 April 1915, Boghos Nubar's Papers, 17; US National Archives, RG 59, 867.4016/59, Morgenthau to Secretary of State, 30 April 1915; RG 59, 867.4016/60, Bryan to Bakhméteff, 3 May 1915; Library of Congress, Division of Manuscripts, Papers of Henry Morgenthau, Sr., General Correspondence, Container 7, Bryan to Morgenthau, 29 April 1915; Aguni, Milion, 303-305.

50. US National Archives, RG 59, 867.4016/60, Bryan to Bakhméteff, 3 May 1915; RG 59, 867.4016/64, Morgenthau to Secretary of State, 6 May 1915.

51. Der Yeghiayan, Memoirs, 82.

52. Aguni, Milion, 197-98; Krieger [Krikor Gergerian], Yosghati Hayasbanutyan vaverakragan badmutyune [The Documentary History of the Armenocide in Yozgat] (New York: Vosgetar, 1980), 168.

53. Makich Arzumanyan, Hayasdan, 1914-1917 [Armenia, 1914-1917] (Yerevan: Hayasdan, 1969), 380-81; Barby, Au pays de l'épouvante, 31.

54. France, A.M.A.E., Guerre 1914-1918, Turquie, "Communication de l'ambassade de Russie au Département," 11 May 1915; "Communication de l'ambassade de Grande-Bretagne au Département," 19 May 1915; "Communication de l'ambassade de Grande-Bretagne au Département," 21 May 1915; "Note du Département à l'Agence Havas," 24 May 1915; M. William Sharp, ambassadeur des États-Unis à Paris, à M. Declassé, ministre des affaires étrangères, 28 May 1915, all in Les grandes puissances: l'empire ottoman et les 
arméniens dans les archives françaises (1914-1918), ed. and comp. Arthur Beylerian 23, 25-26, 27-28, 29, 31 (Paris: Panthéon-Sorbonne, 1983).

55. In fact, Boghos Nubar believed that the Allied Powers had issued the 24 May joint declaration at the initiative of Catholicos Kevork. See Bibliothèque Nubar (Paris), Doc. 67, Boghos Nubar to Catholicos Kevork V, 17 June 1915, Boghos Nubar's Papers, 108-9.

56. Dadrian, History of the Armenian Genocide, 221-22.

57. Der Yeghiayan, Memoirs, 73.

58. Ibid., 73-74; translated text in brackets appears in the original source.

59. Ibid., 77-79; translated text in brackets appears in the original source. Ambassador Morgenthau's diary indicates that he was aware of the meeting between the patriarch and the grand vizier. The diary notes that the patriarch "was given very little encouragement. He says they are determined to revenge themselves for the way they acted in conjunction with the Russians. When he told [the grand vizier that] they should not do so on women and children, he [the grand vizier] did not answer the Patriarch." Library of Congress, Division of Manuscripts, Papers of Henry Morgenthau, Sr., Diary, 11 July 1915.

60. US National Archives, RG 59, 867.4016/119, Page to Secretary of State, 24 August 1915, encl., "Letter received from Constantinople on the situation of the Armenians in Asiatic Turkey," 13 July 1915. See full text in Der Yeghiayan, Memoirs, 85-87.

61. The complete text of the letter, dated 25 May/7 June 1915, appears in Der Yeghiayan, Memoirs, 84-85. See also Aguni, Milion, 113-15. The place names currently used in Turkey appear in parentheses: Gesaria (Kayseri); Dikranagerd (Diyarbekir); Sepasdia (Sivas); Kharpert (Elaziğ); Paghesh (Bitlis).

62. See text of letter, dated 30 June/13 July 1915, in Der Yeghiayan, Memoirs, 85-87.

63. US National Archives, RG 59, 867.4016/78, Catholicos Kevork V to President Wilson, 18 July 1915, and attached translation. See also Simon Payaslian, United States Policy toward the Armenian Question and the Armenian Genocide (New York: Palgrave Macmillan, 2005), 95.

64. Bibliothèque Nubar (Paris), Doc. 105, Catholicos Kevork V to Boghos Nubar, telegram, 18 July 1915, Boghos Nubar's Papers, 180.

65. Bibliothèque Nubar (Paris), 1443-46, Doc. 115, Boghos Nubar to Bishop Ghevont Turian, 21 July 1915, Boghos Nubar's Papers, 197.

66. France, A.M.A.E., Guerre 1914-1918, Turquie, Kevork V, Catholicos of All Armenians, to Viviani, President of the Council, Minister of Foreign Affairs, 5/18 October 1915, in Les grandes puissances: l'empire ottoman et les arméniens dans les archives françaises (1914-1918), ed. and comp. Arthur Beylerian 126-27 (Paris: Panthéon-Sorbonne, 1983).

67. Dadrian, History of the Armenian Genocide, 222-23.

68. "Proteste nützen nichts, und türkische Ableugnungen, daß keine Deportationen mehr vorgenommen werden sollen, sind wertlos." Germany, PA-AA, R14089, Wolff-Metternich, Ambassador, Extraordinary Mission, Constantinople, to Bethmann Hollweg, Reichskanzler, 7 December 1915, in Deutschland und Armenien, 1914-1918: Sammlung Diplomatischer Aktenstücke, by Johannes Lepsius, 201-202 (Potsdam: Tempelverlag, 1919), Doc. 209. An English translation by Linda Struck appears in Gust and Gust, The Armenian Genocide.

69. For an excellent discussion on Musa Dagh, see Vahram Leon Shemmassian, “The Armenian Villagers of Musa Dagh: A Historical-Ethnographic Study, 1840-1915" (PhD diss., University of California, Los Angeles, 1996).

70. Hayasdani Hanrabedutyun, Badmutyan Gendronagan Bedagan Arkhiv [Republic of Armenia, State Central Historical Archives], Doc. 56, f. 57/5/108, Report concerning the Armenian refugees in Port Said, Father Vartan Varteresian, Port Said, to Catholicos Kevork V, Mother See, Echmiadzin, 9 November 1915, in Vaverakrer hay yegeghetsu badmutyan [Documents of the History of the Armenian Church], vol. 4, Sahag II Khabayan, Gatoghigos Giligioy (1891-1940 tt.) [Sahag II Khabayan, Catholicos of Cilicia (1891-1940)], comp. Santro Pehpudyan, 222-25 (Yerevan: Vosgan Yerevantsi, 1997). Ethel W. Putney, an American missionary stationed at Port Said at the time, reported on 
the conditions in a letter written in late December 1915. Ethel W. Putney to Lamson, 23-29 December 1915, ABC:16.9.4, vol. 7, Woman's Board of Missions, Western Turkey, Documents and Reports, 127, vol. 2, Misc. letters, M-Z, 1915-1920, ABCFM Archives, Houghton Library, Harvard University.

71. Aram Andonian, Medz vojire [The Colossal Crime] (Boston: Bahag, 1921; reprint, Yerevan: Arevig, 1990), 102-103.

72. Morgenthau, Ambassador Morgenthau's Story, 305.

73. The following section borrows heavily from Payaslian, United States Policy, 108-10.

74. Der Yeghiayan, Memoirs, 119-22; Papken I. Guleserian, Badmutyun gatoghigosats Giligioy (1441-en minchev mer orere) [History of the Catholicoses of Cilicia (from 1441 until Our Days)] (Antelias: Catholicosate of Cilicia, 1939; reprint, Antelias: Catholicosate of Cilicia, 1990), 925-26, 929-30.

75. Der Yeghiayan, Memoirs, 122.

76. Ibid., 123, 125, 129-75.

77. Walker, Armenia, 408-409.

78. Harry Stuermer, Two War Years in Constantinople, trans. E. Allen (New York: George H. Doran, 1917), 193-94.

79. This excerpt from the letter appears in Der Yeghiayan, Memoirs, 113.

80. HH, BGBA, Doc. 58, f. 57/2/2021, Report concerning the Armenian situation in Jerusalem, Bishop Kud Mkhitarian, Jerusalem, to Catholicos Kevork V, Mother See, Echmiadzin, 3 January 1918, in Vaverakrer hay yegeghetsu badmutyan [Documents of the History of the Armenian Church], vol. 4, Sahag II Khabayan, Gatoghigos Giligioy (1891-1940 tt.) [Sahag II Khabayan, Catholicos of Cilicia (1891-1940)], comp. Santro Pehpudyan, 227-31 (Yerevan: Vosgan Yerevantsi, 1997).

81. Bibliothèque Nubar (Paris), 705-716/718-723, Docs. 122, 123, Boghos Nubar to Catholicos Kevork V, 28 and 29 July 1915, Boghos Nubar's Papers, 209, 215.

82. Bibliothèque Nubar (Paris), 784-791, Doc. 183, Boghos Nubar to Catholicos Kevork V, 23 March 1916, Boghos Nubar's Papers, 326-27. Signed on 26 April 1916, the Sykes-Picot agreement provided for a post-war partition of the Ottoman Empire whereby most of the Arab-speaking areas of the empire would be divided into French and British zones, while Russia would expand into the eastern Ottoman provinces of Trabzon, Erzurum, Bitlis, and Van. See Harry N. Howard, The Partition of Turkey: A Diplomatic History, 1913-1923 (Norman: University of Oklahoma Press, 1931); M.S. Anderson, The Eastern Question, 1774-1923: A Study in International Relations (London: Macmillan, 1966), 340-41; Hovannisian, Armenia on the Road to Independence, $59-60,62$.

83. Bibliothèque Nubar (Paris), 845-850, Doc. 237, Boghos Nubar to Catholicos Kevork V, 11 April 1917, and 851-854, Doc. 238, Catholicos Kevork V to Boghos Nubar, 27 April 1917, Boghos Nubar's Papers, 431-33, 434-35.

84. Germany, PA-AA, R14104, Kressenstein to Hertling, 4 August 1918, in Deutschland und Armenien, 1914-1918: Sammlung Diplomatischer Aktenstücke, by Johannes Lepsius, 420-21 (Potsdam: Tempelverlag, 1919), Doc. 424. An English translation by Vera Draack appears in Gust and Gust, The Armenian Genocide.

85. Dadrian, History of the Armenian Genocide, 221-22.

86. Yeghiayan, Zhamanagagits badmutyun, 34, 57-58.

87. Teotig [Teodos Lapjinjian], Amenuyn daretsuytse [Everyone's Almanac] (Constantinople: M. Hovagimian, 1921), 144-45; Der Yeghiayan, Memoirs, 173, 175.

88. Orphan Collection Agency (Vorpahavak marmin); Orphan Care Agency (Vorpakhnam marmin); Society for Deportees (Darakrelots engerutyun); Armenian National Trusteeship (Hay azkayin khnamagalutiun). Der Yeghiayan, Memoirs, 175-76, 182.

89. In Armenian, Gesaratsineru hayrenagtsagan miutiun.

90. Der Yeghiayan, Memoirs, 177, 178-79, 182, 186; Chormisian, Hamabadger, 587-89, 595; Simon Payaslian, "United States Policy toward the Armenian Question and the Armenian Genocide" (PhD diss., UCLA, 2003), 628-30. 
91. See, for example, Hayasdani Hanrabedutyun, Badmutyan Gendronagan Bedagan Arkhiv [Republic of Armenia, State Central Historical Archives], Doc. 155, f. 57/5/211, Gen. Antranig to Catholicos Kevork V, Mother See, Echmiadzin, 10 November 1919, in Vaverakrer hay yegeghetsu badmutyan [Documents of the History of the Armenian Church], vol. 5, Mayr ator S. Echmiadzine arachin hanrabedutyan darinerin (1918-1920 tt.) [The Mother See, Holy Echmiadzin, during the Years of the First Republic (1918-1920)], comp. Santro Pehputyan, 199-200 (Yerevan: Vosgan Yerevantsi, 1999). See also Richard G. Hovannisian, The Republic of Armenia, 4 vols. (Berkeley and Los Angeles: University of California Press, 1971-1996).

92. HH, BGBA, Doc. 62, f. 57/2/2033, Report concerning the events during World War I, Patriarch Zaven, Constantinople, to Catholicos Kevork V, Mother See, Echmiadzin, 12 May 1919, in Vaverakrer hay yegeghetsu badmutyan [Documents of the History of the Armenian Church], vol. 4, Sahag II Khabayan, Gatoghigos Giligioy (1891-1940 tt.) [Sahag II Khabayan, Catholicos of Cilicia (1891-1940)], comp. Santro Pehpudyan, 237-40 (Yerevan: Vosgan Yerevantsi, 1997).

93. HH, BGBA, Doc. 59a, Eghishe Charents Museum, V. Malezian papers, Doc. 9981, Catholicos Sahag to Gen. Allenby, 8 January 1919, in Vaverakrer hay yegeghetsu badmutyan [Documents of the History of the Armenian Church], vol. 4, Sahag II Khabayan, Gatoghigos Giligioy (1891-1940 tt.) [Sahag II Khabayan, Catholicos of Cilicia (1891-1940)], comp. Santro Pehpudyan, 233-34 (Yerevan: Vosgan Yerevantsi, 1997).

94. HH, BGBA, Doc. 60, Catholicos Sahag to Boghos Nubar, 17 April 1919, in Vaverakrer hay yegeghetsu badmutyan [Documents of the History of the Armenian Church], vol. 4, Sahag II Khabayan, Gatoghigos Giligioy (1891-1940 tt.) [Sahag II Khabayan, Catholicos of Cilicia (1891-1940)], comp. Santro Pehpudyan, 234-36 (Yerevan: Vosgan Yerevantsi, 1997).

95. Payaslian, "United States Policy," 636-37; Richard G. Hovannisian, The Republic of Armenia, vol. 2, From Versailles to London, 1919-1920 (Berkeley and Los Angeles: University of California Press, 1982), 416; Chormisian, Hamabadger, 551; Stanley E. Kerr, The Lions of Marash (Albany: State University of New York Press, 1973), 36; T.H. Greenshields, "The Settlement of Armenian Refugees in Syria and Lebanon, 1915-1939" (PhD diss., Durham University, 1978), 57.

96. Yeghiayan, Zhamanagagits badmutyun, 109-29, 159-61, 209.

97. The Catholicosate of Cilicia was transferred in 1924 to Antelias, Lebanon, where it remains to this day. Ibid., 282.

98. Ibid., 280-81; Payaslian, United States Policy, 145; Chormisian, Hamabadger, $515-17,522$.

99. For other estimates, see Dickran Kouymjian, "Confiscation and Destruction: A Manifestation of the Genocidal Process," Armenian Forum 1:3 (1998): 1-12.

100. Ormanian, Church of Armenia, appendices II and III, 239-45; Sarkissian, "Armenian Church," 492. The combined total of Armenian Protestants and Catholics within the jurisdiction of both the Patriarchate at Constantinople and the Catholicosate of Cilicia numbered about 118,400 individuals prior to the war; in 1954, that figure stood at 43,090, 9,500 of whom were in Turkey and 33,590 in the diaspora. Ormanian, ibid.

101. Sarkissian, "Armenian Church," 492.

102. On the first decision by the Armenian Church at Echmiadzin to commemorate the genocide, see Simon Payaslian, "April 24: A Decision to Commemorate," Armenian MirrorSpectator, 23 April 2005, 12.

103. HH, BGBA, Doc. 270, f. 57/5/217, Vrtanes Papazian to Catholicos Kevork V, 25 March 1920; Doc. 271, f. 207/1/249, Papazian to the Parliament of the Republic of Armenia, 25 March 1920; Doc. 272, f. 57/5/217, Catholicosate, Circular, 26 March 1920, all in Vaverakrer hay yegeghetsu badmutyan [Documents of the History of the Armenian Church], vol. 5, Mayr ator S. Echmiadzine arachin hanrabedutyan darinerin (1918-1920 tt.) [The Mother See, Holy Echmiadzin, during the Years of the First Republic (1918-1920)], comp. Santro Pehputyan, 360-64 (Yerevan: Vosgan Yerevantsi, 1999). 


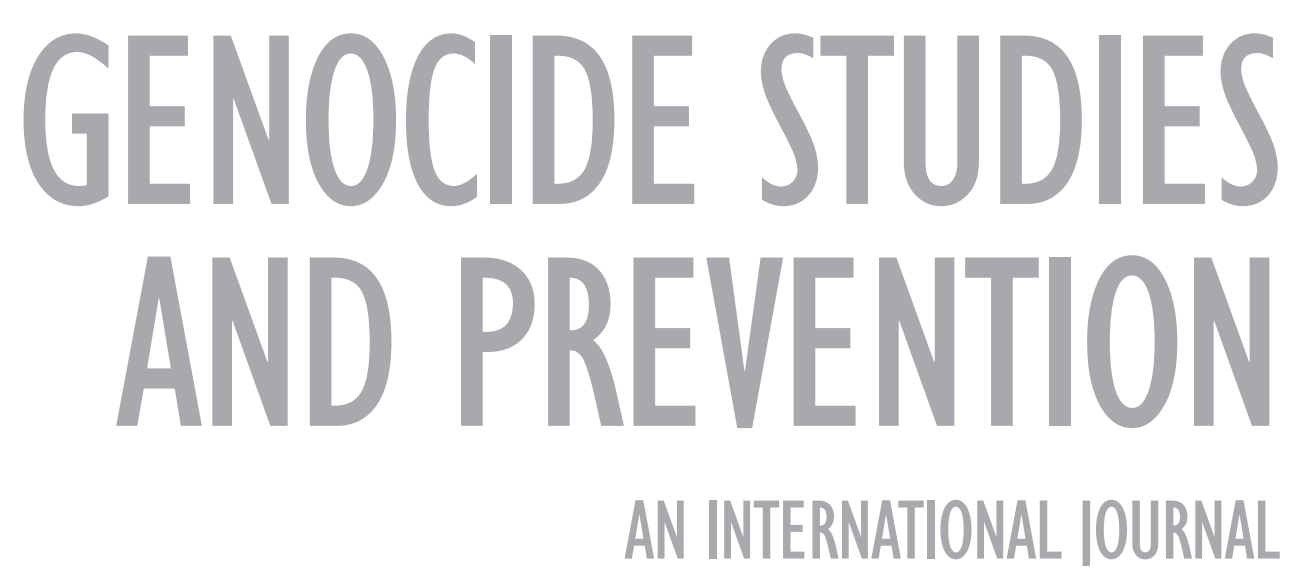

